\title{
Price Competition, Regulation, and Systematic Underwriting Risk in Automobile Insurance
}

\author{
by Robert C. Witt * and Jorge Urrutia **
}

\section{Introduction}

Insurance regulation in the U.S. is conducted by the states. There are 51 independent jurisdictions (including the District of Columbia) and, therefore, 51 insurance laws to regulate the activities of insurance companies, many of which do business in several or all of the states. In European countries, on the other hand, insurance regulation is the responsibility of the central government, and there are uniform rules for regulating the operations of insurers. However, the differences between the American states are ameliorated by the fact that a small number of large states have reached leading regulatory positions and their regulatory policies heavily influence or are followed by the other states. Moreover, the National Association of Insurance Commissioners tries to promote the development of uniform state laws.

The insurance rate regulatory systems in the U.S. should be of particular interest to the European Economic Community (EEC). Although the EEC to a large extent leaves the matter of insurance regulation to the individual countries, efforts are being made to create more homogeneous insurance markets and to reduce the barriers to entry for foreign insurers in the member countries. In this respect, the long experience and the performance of the state regulatory systems in the U.S. may provide some insights for Europeans.

Empirical studies of the performance of state rate regulatory systems in the U.S. should be relevant to the European legislators and regulators, especially those in the EEC. The issue of whether or not insurance rates should be regulated is an important and polemic matter in many countries. In particular, intense interest in the purpose, benefits, and social and economic costs of insurance rate regulation has developed in recent years in the U.S. Various studies about rate regulation in automobile insurance have been conducted by academic, legislative, regulatory, and industry groups. The results of these studies basically suggest that rate regulation has little or no effect on

* The Joseph H. Blades Centennial Memorial Professor of Insurance and Risk Management, Graduate School of Business, University of Texas at Austin. The support of the CBA Foundation at the University of Texas at Austin is gratefully acknowledged.

** Ph.D. candidate in Finance and Insurance, Graduate School of Business, University of Texas at Austin. 
relative prices in automobile insurance markets and that it does not hold prices below equilibrium levels attained in unregulated competitive markets. Thus, many of the studies conclude that it is reasonable to depend on price competition to protect the interests of consumers when an automobile insurance market is competitively structured. ${ }^{1}$ The results of this more extensive empirical study provide additional support for conclusions reached in earlier studies and also add some important economic insights about the relation between systematic underwriting risk and rate regulation.

The purpose of this study is to analyze the impact of price competition on automobile insurance loss ratios by state and company group for the period 1971 through 1980 in the United States. The analysis is based on separate or disaggregated data for automobile liability and physical damage insurance for this time period. Analysis of these distinct automobile insurance lines shows that there are some substantial differences in systematic underwriting risk between them. In general, we found that there was much greater systematic underwriting risk associated with automobile physical damage insurance than with automobile liability insurance, regardless of the type of rate regulatory law. This was somewhat surprising because we expected to find the opposite.

We also found that there were no significant differences between the mean loss ratios or relative prices in competitive and "non-competitive" rate states for direct writers, independent agency companies, and for the entire industry. ${ }^{2}$ However, some large differences in mean loss ratios were found between the ratios for some of the purest laws in these two broad rate regulatory classifications.

Market share data by state and company group are also analyzed here. Similar to Witt and Miller [15], we found that direct writers had larger mean market shares in competitive rate states than non-competitive ones. The opposite relationship was found for national agency companies. These results seem to suggest that the aggressive pricing strategy of direct writers was more successful in competitive rate states than in noncompetitive ones, which seems to have important public policy implications about the benefits of price competition. Although rate regulation constrained direct writers somewhat in highly regulated rate states, they still captured the largest share of the market in these states. Nevertheless, rate regulation appears to have denied consumers some of the benefits provided by the competitively priced products of direct writers. Rate regulation may mislead consumers into believing that prices do not differ among automobile insurers in price regulated markets.

The paper is organized in the following manner. In Section II, a brief overview of the purpose of insurance regulation is presented. In Section III, we explain how we classified and partitioned the eight different types of rate regulatory laws into the competitive and non-competitive rate regulatory categories. In Section IV, we discuss

1 For example, see the following studies : Ippolito [3], Samprone [9], General Accounting Office Report [2], U.S. Department of Justice Report [10], New York Insurance Department Report [7], O'Connor and Carlson [8], Witt [11, 12], and Witt and Miller [14, 15].

2 "Non-competitive" rate regulatory states are defined to mean those states with rate regulatory statutes which limit or constrain price competition in some manner in the automobile insurance market. Direct writers generally market insurance through exclusive agents or salaried sales representatives; whereas, independent agency companies use independent agents who represent more than one insurer. 
the data utilized, the economic rationale for the use of a loss ratio as a relative cost measure, and the various underwriting concepts utilized in the study. The various hypotheses we tested are also specified and explained in this section. In Section V, the results concerning the analyses of loss ratios and market shares for the purest forms of state rate regulatory laws in the competitive and non-competitive rate regulatory categories are presented. In Section VI, the nature of underwriting risk and the regression model utilized in measuring the systematic and unsystematic components of underwriting risk are explained. The results obtained for some of the purest rate regulatory laws in the broad regulatory categories and for the competitive and noncompetitive rate regulatory systems are also discussed. Finally, in Section VII, we briefly summarize and conclude the paper.

\section{An overview of insurance regulation}

One might ask why is insurance regulated ? Insurance is regulated basically because it involves a future performance contract which is dependent upon the solvency of the insurance enterprise. Since insurance involves a future performance contract, prices must be established before costs are known. Insurance consumers pay the premium set by the insurer in return for a promise that they will be compensated if any of the contingent losses covered by the insurance contract occur during the term of the policy. The existence of a market for insurance is, therefore, highly dependent upon the consumer's confidence in the insurer's integrity and ability to pay for potential future losses covered under the contract. Clearly, the economic viability of an insurance market is dependent on the long-term financial solvency of the insurance enterprise. As a consequence, the insurance industry is closely regulated to preserve the solvency of companies. Regulation includes numerous aspects related to the formation of insurers, minimum capital and surplus requirements, policy provisions, accounting methods, marketing practices, investment policies, claim settlement practices, underwriting standards, and the prices charged for the insurance contract. 3

Now one might ask why are property and liability insurance rates regulated? There probably is no single persuasive answer to this question. It has frequently been argued that insurance prices are regulated in order to protect insurance consumers and to prevent insolvencies of insurers. It is not clear, however, that rate regulation accomplishes these objectives. In fact, many regulators seem to feel their purpose is to hold rates down whether or not market conditions justify such political behavior. Historically, rate regulation in the U.S.A. developed in the late 1800's for fire insurance when intense competition in this area of insurance led to rates which were too low and eventually resulted in some major insolvencies, which left many policyholders with unpaid claims. Hence, ratemaking bureaus were encouraged to develop joint non-competitive rates in fire insurance in order to assure adequacy. Similar price setting cartels were later established in automobile insurance. When some questions were raised about the legality of the price fixing activities of these cartels in the 1940's, many states passed

3 For a more detailed discussion of the general purpose of insurance regulation, see Kimball [5] and Witt and Miller [15]. 
rate regulatory laws in order to protect ratemaking bureaus in property and liability insurance from prosecution under federal antitrust laws in the U.S.A. Most of these rate regulatory laws indicated that rates should not be inadequate, excessive, or unfairly discriminatory.

The rate standards for inadequacy and excessiveness seem to be premised on the assumption that competitive market forces in a state cannot determine equilibrium levels of automobile insurance rates without outside regulatory intereference. The unfairly discriminatory rate standard is based on equity concepts associated with social and ethical goals of society. Yet, it is not clear that these rate standards help to promote insurer solvency and to protect insurance consumers.

\section{Classiflcation of rate regulatory laws}

The way automobile insurance rates are regulated in the U.S.A. varies among the 50 states and the District of Columbia. Regulatory approaches vary from state-set rates in Texas to no rate regulation in Illinois. Nevertheless, the eight different types of rate regulatory laws in effect in the United States have some similar economic characteristics and can be broadly classified as competitive and non-competitive laws (or less competitive laws in that constraints are placed on competitive market forces).

States with competitive rate regulatory laws basically allow the competitive market forces of supply and demand to determine the equilibrium level of rates for the various automobile insurance contracts. States with non-competitive rate regulatory laws possess the common trait of constraining rates in various ways which do not allow the economic forces of supply and demand to be fully operative and tend to interfere with equilibriating market forces. 4

It should be noted that when a state changed the nature of its law during the ten-year period the law assigned to the state for analytic purposes is the one which was in effect for the longest time period. When we grouped the state rate regulatory laws into the two broad categories of competitive and non-competitive laws, we attempted to recognize not only the "letter" of the law, but also the "spirit" and the administration of it. For analytic purposes, we placed 17 states in the competitive rate regulatory category and 33 states plus the District of Columbia in the non-competitive one.

\section{Nature of analysls}

\subsection{Data utilized}

In order to contrast and compare relative costs and underwriting risk for automobile liability and physical damage insurance under competitive and non-competitive

4 For a detailed discussion of the eight types of rate regulatory laws in effect in the United States, see Witt and Miller [15, pp. 206-207]. 
rate regulatory laws, some dividend-adjusted loss ratio data by state were obtained from the A. M. Best Company for 1971 through 1980. 5 These statewide loss ratios were obtained separately for automobile liability and physical damage insurance and on a combined basis for these two lines. ${ }^{6}$ Moreover, separate sets of data for direct writers, national agency companies, regional-specialty companies, and for all of these companies combined (the entire industry) were also obtained on a segregated basis.

Each set of loss ratios by automobile insurance line and company group were statistically analyzed in order to determine how relative costs and underwriting risk differed between non-competitive and competitive rate regulatory states. Some marketshare data by line and by state for direct writers, national agency companies, and regional-specialty companies for this time period were also obtained and analyzed. Based on this annual loss ratio and market share data, various financial and statistical measures were developed and analyzed.

\subsection{Loss ratios as relative-cost measures}

Dividend-adjusted loss ratios by state were used as relative cost measures in this paper because they reflect the portion of the premium dollar for automobile insurance returned to consumers in the form of loss payments in each state. Accordingly, this ratio shows some of the direct benefits that insurance consumers obtain in return for their premium payments.

Comparisons of loss ratios among states are easier to interpret and more useful for analytic purposes than comparisons of average rates because loss ratios are standardized relative-cost measures. Average state rates are absolute-cost measures which are determined by differences in mean claim frequencies and severities among states. Thus, these rates cannot be compared directly unless a major multivariate regression model is developed to control for numerous possible differences among states, Differences in mean claim frequencies and claim severities among states for automobile insurance are reflected in both losses and premiums. Thus, when losses are divided by earned premiums to obtain a loss ratio, differences due to variation in weather conditions, traffic density, traffic law enforcement, and a host of other factors tend to cancel out of the ratio. In this respect, a relative-cost measure is much better for comparison

5 The dividend-adjusted loss ratio is defined as the ratio of incurred losses (not including loss adjustment expenses) to earned premiums after policvholders dividends, if any. Policyholders dividends were deducted from earned premiums before the loss ratios were computed. Accordingly, the losses are compared to actual premiums earned after dividends in each state.

6 The dividend-adjusted loss ratios reflect the loss experience of all companies writing automobile insurance in each state and the District of Columbia, except for some small county and township mutuals. The loss ratios for calendar years 1971, 1972, and 1975 through 1980 reflect the automobile insurance experience for both commercial and private-passenger automobiles. The loss ratios for 1973 and 1974 include only the private passenger automobile insurance experience because commercial experience was not combined and presented with private passenger data on a state-by-state basis by the A. M. Best Company for these years. According to Best's Review, approximately 18 percent of the total automobile insurance sold in the United States during these two years was on commercial vehicles. This means that at least 80 percent of the automobile insurance business in the United States is reflected in the loss ratios for 1973 and 1974, which seems to be adequate for the purposes of our study. 
purposes than an absolute-cost measure, which does not allow for the various differences among states. ${ }^{7}$

Cost comparisons based on loss ratios are subject to some common sense constraints that recognize the impact of political interference on prices and loss ratios. For example, the state with the highest loss ratio does not necessarily indicate that it has the best form of rate regulation because political pressures may encourage regulators to artificially inflate loss ratios by suppressing prices. If loss ratios are higher than a competitive market equilibrium would generate and insurers are incurring major underwriting losses in the state due to political or bureaucratic interferences with the market pricing mechanism, one cannot reasonably conclude the rate regulatory law in such a state is better than those in other states. Such a political situation could force insurers to reduce sales or to stop writing insurance in such a state (the availability problem) or, possibly, to become insolvent (the reliability problem). 8 Nevertheless, if one recognizes the constraints associated with an analysis of loss ratios, some useful insights can be obtained.

It should be noted that actual and expected loss ratios can differ slightly among states because of some minor differences in expense provisions, such as premium taxes. ${ }^{9}$ Differences in percentage distributions of premium volume for independent agency insurers and direct writers among states might also affect the magnitude of loss ratios by state for the entire industry. However, this latter problem was eliminated by making separate comparisons for each company group with a distinct marketing system.

\subsection{Financial and statistical measures}

Based on annual loss ratios and market shares by state for each company group and the entire industry, various financial and statistical measures were developed and analyzed. In particular, premium-weighted averages of the loss ratios by state, company group, and line were developed along with standard deviations of these loss ratios. The mean loss ratio is an inverse measure of relative profitability in a state because underwriting profit rates tend to vary inversely with loss ratios. ${ }^{10}$ The standard deviation is

7 For a more detailed discussion of this point, see Robert C. Witt [12].

8 During recent years, such a situation seems to have developed in New Jersey. Political turbulence seems to have brought about a lot of interference with the pricing process and may have harmed rather than helped automobile insurance consumers in this state in the long run.

- An attempt was made to obtain some expense ratio data by state for each company group. Unfortunately, the A.M. Best Company only has such data on a nationwide basis, although it sometimes allocates expenses to states in accordance with premium volume. Thus, it was not possible to analyze combined ratios by state, which would reflect both loss and expense results. However, some expense ratio data for 1978 were obtained from the National Association of Insurance Commissioners (NAIC) and analyzed in order to determine if our results might be seriously affected by excluding expenses. Based on this analysis, it was found that expenses do not differ significantly among the states. However, there were some slight variations in expense ratios due to differences in premium taxes among states. The expense ratio data were obtained from the NAIC Report [6].

10 For an algebraic explanation of why underwriting profit rates tend to vary inversely with loss ratios, see Witt [13]. 
merely a statistical measure which shows how the magnitude of the annual loss ratios in a state varies around the average state loss ratio during a given time period.

Although there is not complete agreement on how to define and measure underwriting risk, it seems clear that it is associated with the uncertainty or the unpredictability of underwriting results. As a proxy, the variability in annual loss ratios by state reflects this uncertainty on an ex post basis. Accordingly, the temporal variability in these loss ratios is used as a measure of total underwriting risk for automobile insurance in a state. This risk measure can be split into two parts : the systematic and unsystematic components. The systematic component of underwriting risk is determined by regressing a state loss ratio for a given automobile insurance line on the national automobile insurance loss ratio for all lines during a given time period. The resulting measure is referred to as "beta" and shows how the state loss ratio varies with respect to the national ratio on a relative basis. The remaining variability, which is not explained by the national loss ratio, is the unsystematic components of underwriting risk.

\subsection{Expectations and hypotheses}

Some expectations about what might be discovered were formulated before the loss ratios were analyzed. These a priori expectations were treated as hypotheses and statistically analyzed.

Mean loss ratios by state and line were initially expected to be higher in competitive rate states than in non-competitive ones because we believed competitive market pressures would force insurers to return a higher proportion of the premium dollar to consumers through the payment of insured losses. To test this hypothesis, differences in mean loss ratios between states with competitive and non-competitive types of rate regulatory laws were tested for statistical significance. Somewhat surprisingly, we found our expectations were not correct. In essence, we found no significant differences in relative costs between competitive and non-competitive rate states over the ten-year period analyzed for most company groups and lines of automobile insurance.

The second set of hypotheses was concerned with mean market shares. A priori, we expected direct writers to have larger market shares in competitive rate states than in non-competitive ones. In contrast, we expected the opposite for national agency companies. Since direct writers have been capturing a growing share of the automobile insurance market with their competitive pricing strategy, we expected them to capture a relatively larger share of the market in competitive rate states than in non-competitive ones, where they appear to be less aggressive in their pricing because of the uncertainty imposed upon them by regulatory delays. They may also try to avoid the bureaucratic hassles associated with rate reviews in non-competitive rate states. Some strong statistical support was found for both of these hypotheses.

The third hypothesis was concerned with "sticky" prices in regulated or noncompetitive rate states. A priori, we expected loss ratios to be more variable over time in non-competitive rate states than in competitive ones. Prices can generally be adjusted smoothly over time as costs rise in competitive rate states. In contrast, this is usually not possible in non-competitive rate states. In contrast, this is usually not possible in non-competitive rate states because of the delays and lags inherent in the rate review process which prevent smooth adjustments in prices as costs change. In general, rates 
in regulated states tend to be somewhat "sticky" because of the review and approval process. Accordingly, loss ratios would be expected to fluctuate more in non-competitive rate states than in competitive ones because of delayed price adjustments. We found some statistical support for such a hypothesis for automobile physical damage insurance.

The above hypothesis is concerned with the total variability in loss ratios, which may not be the appropriate test for determining the impact of price regulation because it contains both the systematic and unsystematic components of loss ratio variability. A better test for the impact of rate regulation on the variability in loss ratios could be based on the systematic component. In this regard, we expected the systematic component of the variability in loss ratios for a state to be greater in non-competitive rate states than in competitive ones. We found statistical support for this hypothesis for most company groups and automobile lines.

\section{Analysis of mean loss ratios and mean market shares}

Mean loss ratios and mean market shares for 1971 through 1980 for the various automobile insurance lines are compared and contrasted for the company groups and the two broad competitive classifications of states. The results are shown separately for the various company groups with distinct and mixed marketing systems and for the total industry for each automobile insurance line.

\subsection{Results under regulatory extremes}

In assessing the economic results under competitive and non-competitive rate regulatory laws, perhaps the most meaningful insights can be obtained by comparing and contrasting the extreme rate regulatory laws in each of the broad regulatory classifications. In this regard, three states were selected in order to determine some of the differences between the extremes or the purest forms of laws in the two broad rate regulatory classifications. The states selected for this analysis were California, Illinois and Texas. In the competitive rate classifications, California and Illinois were chosen as examples of states having highly competitive rate regulatory systems. In the non-competitive classification of regulatory laws, Texas was selected because it represents one of the regulatory extremes for constraining price competition. Rates for all insurers writing automobile insurance in Texas, except for a few county mutuals, are set by the State Board of Insurance, a public price fixing group. This is a cartel type of arrangement sanctioned by the State of Texas. However, deviations from these state-set rates are permitted.

Mean loss ratios and the mean market shares for these three states, along with the corresponding ranks by magnitude (the ranks are from high to low for all states and the District of Columbia) are presented in Tables 1.1, 1.2, and 1.3. The results are shown separately for each of the company groups writing automobile insurance in each jurisdiction and jointly for all of the companies in the industry in each line of insurance. Table 1.1 shows the results for all automobile insurance lines combined for 1971 through 1980. Tables 1.2 and 1.3 show the results for automobile liability and physical damage insurance during this period, respectively. 
Table 1.1

Comparison of the mean loss ratios and mean market shares for California, Illinois, and Texas for all automobile insurance lines during 1971-1980

\begin{tabular}{|c|c|c|c|c|c|c|c|c|}
\hline \multicolumn{9}{|c|}{ MEAN LOSS RATIOS } \\
\hline & \multicolumn{2}{|c|}{ Direct Writers } & \multicolumn{2}{|c|}{ National Agency } & \multicolumn{2}{|c|}{$\underline{\text { Regional Companies }}$} & \multicolumn{2}{|c|}{ Industry } \\
\hline & $\begin{array}{l}\text { Mean Loss } \\
\quad \text { Ratio } \\
\end{array}$ & Rank & $\begin{array}{l}\text { Mean Loss } \\
\quad \text { Ratio } \\
\end{array}$ & $\underline{\text { Rank }}$ & $\begin{array}{l}\text { Mean Loss } \\
\text { Ratio } \\
\end{array}$ & $\underline{\text { Rank }}$ & $\begin{array}{c}\text { Mean Loss } \\
\quad \text { Ratio } \\
\end{array}$ & $\underline{\text { Rank }}$ \\
\hline California & $66.7 \%$ & 24 & $61.6 \%$ & $\overline{26}$ & $57.7 \%$ & $\overline{45}$ & $64.2 \%$ & 24 \\
\hline Illinois & 66.9 & 23 & 60.7 & 32 & 58.9 & 37 & 63.9 & .26 \\
\hline Texas & 65.0 & 34 & 63.0 & 21 & 56.4 & 48 & 62.5 & 33 \\
\hline National & 67.6 & - & 63.2 & - & 61.7 & - & 64.9 & - \\
\hline \multicolumn{9}{|c|}{$M E A N$ MARKET SHARES } \\
\hline & \multicolumn{2}{|c|}{ Direct Writers } & National Ag & ency & \multicolumn{2}{|c|}{ Regional Companies } & & \\
\hline & $\begin{array}{c}\text { Mean Market } \\
\text { Share } \\
\end{array}$ & $\underline{\text { Rank }}$ & $\begin{array}{l}\text { Mean Market } \\
\text { Share }\end{array}$ & Rank & $\begin{array}{c}\text { Mean Market } \\
\text { Share }\end{array}$ & Rank & & \\
\hline California & $64.8 \%$ & 2 & $23.2 \%$ & $\overline{45}$ & $11.1 \%$ & $\overline{43}$ & & \\
\hline Illinois & 52.5 & 22 & 26.5 & 33 & 20.6 & 17 & & \\
\hline Texas & 46.8 & 35 & 36.2 & 11 & 16.8 & 30 & & \\
\hline National & 50.1 & - & 32.0 & - & 17.8 & - & & \\
\hline
\end{tabular}

Table 1.2

Comparison of the mean loss ratios and mean market shares for California, Illinois and Texas for automobile liability insurance during 1971-1980

\begin{tabular}{|c|c|c|c|c|c|c|c|c|}
\hline \multicolumn{9}{|c|}{ MEAN LOSS RATIOS } \\
\hline & \multicolumn{2}{|c|}{ Direct Writers } & \multicolumn{2}{|c|}{ National Agency } & \multicolumn{2}{|c|}{ Regional Companies } & \multicolumn{2}{|c|}{ Industry } \\
\hline & $\begin{array}{c}\text { Mean Loss } \\
\text { Ratio } \\
\end{array}$ & $\underline{\text { Rank }}$ & $\begin{array}{c}\text { Mean Loss } \\
\text { Ratio } \\
\end{array}$ & $\underline{\text { Rank }}$ & $\begin{array}{c}\text { Mean Loss } \\
\text { Ratio } \\
\end{array}$ & $\underline{\text { Rank }}$ & $\begin{array}{c}\text { Mean Loss } \\
\text { Ratio } \\
\end{array}$ & $\underline{\text { Rank }}$ \\
\hline California & $66.0 \%$ & 20 & $63.0 \%$ & 27 & $60.1 \%$ & 28 & $64.7 \%$ & 19 \\
\hline Illinois & 64.0 & 28 & 59.8 & 36 & 55.7 & 47 & 61.3 & 37.5 \\
\hline Texas & 62.4 & 36 & 63.3 & 23 & 59.3 & 34 & 61.9 & 31 \\
\hline National & 67.2 & - & 64.4 & - & 62.7 & - & 65.2 & - \\
\hline \multicolumn{9}{|c|}{ MEAN MARKET SHARES } \\
\hline & \multicolumn{2}{|c|}{ Direct Writers } & \multicolumn{2}{|c|}{ National Agency } & \multicolumn{2}{|c|}{ Regional Companies } & & \\
\hline & $\begin{array}{c}\text { Mean Market } \\
\text { Share }\end{array}$ & $\underline{\text { Rank }}$ & $\begin{array}{l}\text { Mean Market } \\
\text { Share }\end{array}$ & Rank & $\begin{array}{c}\text { Mean Market } \\
\text { Share }\end{array}$ & $\underline{\text { Rank }}$ & & \\
\hline California & $65.0 \%$ & 2 & $25.1 \%$ & 46 & $9.4 \%$ & 47 & & \\
\hline Illinois & 50.0 & 23 & 28.9 & 35 & 20.9 & 13 & & \\
\hline Texas & 45.9 & 35 & 39.9 & 12 & 13.9 & 34 & & \\
\hline National & 49.0 & - & 34.2 & - & 16.8 & - & & \\
\hline
\end{tabular}


Table 1.3

Comparison of the mean loss ratios and mean market shares for California, Illinois and Texas for automobile physical damage insurance during 1971-1980

\begin{tabular}{|c|c|c|c|c|c|c|c|c|}
\hline \multicolumn{9}{|c|}{ MEAN LOSS RATIOS } \\
\hline & \multicolumn{2}{|c|}{ Direct Writers } & \multicolumn{2}{|c|}{ National Agency } & \multicolumn{2}{|c|}{ Regional Companies } & \multicolumn{2}{|c|}{ Industry } \\
\hline & $\begin{array}{l}\text { Mean Loss } \\
\text { Ratio } \\
\end{array}$ & $\underline{\text { Rank }}$ & $\begin{array}{c}\text { Mean Loss } \\
\text { Ratio }\end{array}$ & $\underline{\text { Rank }}$ & $\begin{array}{l}\text { Mean Loss } \\
\text { Ratio }\end{array}$ & $\underline{\text { Rank }}$ & $\begin{array}{c}\text { Mean Loss } \\
\quad \text { Ratio } \\
\end{array}$ & $\underline{\text { Rank }}$ \\
\hline California & $\overline{68.3 \%}$ & $\overline{25}$ & $\overline{58.9 \%}$ & $\overline{30}$ & $\overline{54.9 \%}$ & $\overline{41}$ & $\overline{63.6 \%}$ & 30 \\
\hline Illinois & 71.3 & 10 & 62.8 & 13 & 64.2 & 13 & 68.3 & 7 \\
\hline Texas & 68.2 & 26 & 62.6 & 15 & 54.1 & 44 & 63.3 & 31 \\
\hline National & 68.1 & - & 60.9 & - & 60.4 & - & 64.5 & - \\
\hline \multicolumn{9}{|c|}{ MEAN MARKET SHARES } \\
\hline & \multicolumn{2}{|c|}{ Direct Writers } & National $\mathrm{Ag}$ & ency & \multicolumn{2}{|c|}{ Regional Companies } & & \\
\hline & $\begin{array}{l}\text { Mean Market } \\
\text { Share }\end{array}$ & $\underline{\text { Rank }}$ & $\begin{array}{l}\text { Mean Market } \\
\text { Share }\end{array}$ & Rank & $\begin{array}{l}\text { Mean Market } \\
\text { Share }\end{array}$ & Rank & & \\
\hline California & $64.2 \%$ & $\overline{3}$ & $20.0 \%$ & $\overline{46}$ & $14.4 \%$ & $\overline{40}$ & & \\
\hline Illinois & 56.3 & 18 & 22.9 & 34 & 20.2 & 25 & & \\
\hline Texas & 47.8 & 36 & 31.8 & 14 & 20.3 & 24 & & \\
\hline National & 51.6 & - & 28.7 & - & 19.5 & - & & \\
\hline
\end{tabular}

\section{Mean Loss Ratios}

By examining the mean loss ratios in Table 1.1, it can be observed that the mean loss ratio for each automobile insurance lines in Texas is almost always less than the corresponding loss ratios in California and Illinois for each company group (except for national agency companies), and the entire industry. Therefore, a higher proportion of the premium dollar was returned to consumers in the form of loss payments in California and Illinois than in Texas. This indicates that the relative cost of automobile insurance (the price per dollar of loss payment) tends to be lower in the two competitive rate states than in Texas. ${ }^{11}$ Since the mean loss ratio is also an inverse measure of underwriting profit from an insurer's viewpoint, these results may indicate that insurers were able to make larger underwriting profits, or incurred smaller underwriting losses, in Texas than in Illinois and California for both automobile insurance lines. 12

When the automobile insurance insurance results are disaggregated in Tables $\mathbf{1 . 2}$ and $\mathbf{1 . 3}$ for automobile liability and physical damage, the results are somewhat different. For automobile liability insurance, California has the highest loss ratio for each company group except for the national agency companies. However, the loss ratio in Texas

11 The premium tax percentage is slightly higher in Texas than in California and Illinois, which accounts for a small part of the difference observed here.

12 Of course, it is possible that non-price competition in the form of services not associated with loss payments might consume any potential excess profits in Texas. For discussion of this possibility, see Samprone [9]. 
in frequently higher than the one in Illinois except for the direct writers. For automobile physical damage insurance, Illinois always has the highest loss ratio and California has the second highest loss ratio for every company group, except for national agency companies.

In general, these relative cost comparisons seem to suggest that consumers are obtaining more loss benefits per premium dollar in the two competitive rate states than in Texas for both automobile insurance lines combined. This fact seems to suggest that automobile insurance consumers tend to fare relatively better under highly competitive pricing systems than under a tightly regulated system, such as the one in Texas. Hence, one of the most stringent forms of price regulation involving state-set rates does not guarantee consumers lower relative costs that those achieved under competitive rating systems. The results, in fact, seem to suggest the exact opposite. In this regard, consumers might be better off with competitively determined rates in Texas.

The highest mean loss ratio for each company group and the total industry for the various automobile insurance lines almost always occurred in New Jersey. New Jersey seems to illustrate the caveat stated earlier that the highest loss ratio does not always indicate the best form of rate regulation. This state has a prior-approval rate regulatory law which has encouraged a large amount of regulatory and political interference with the operation of the pricing system and equilibriating market forces. This state regulatory scheme seems to demonstrate why rate should not be politically regulated when there are sufficient number of competitors such that market forces can determine equilibrium levels.

High loss ratios are desirable from a consumer's viewpoint when they result from the voluntary actions of companies competing in a free market. They are not desirable when they result from involuntary actions imposed upon companies by politically inspired regulators rather than by impersonal market forces.

\section{Mean Market Shares}

By examining the three tables, it can be seen that the direct writers had larger mean market shares in the two competitive rate states than in Texas. That is, they captured a larger portion of automobile insurance business in California and Illinois than they did in Texas. The exact opposite relationship was found for the national agency companies. No consistent pattern could be observed for the regional companies.

Comparisons among the company groups show direct writers always have the largest market share in a state and the national agency companies have the second highest value. The regional companies have the lowest share.

\subsection{Results in competitive and non-competitive states}

In Tables 2.1, 2.2, and 2.3, the results of the analysis of mean loss ratios and mean market shares for all of the states and the District of Columbia after they were partitioned into the competitive and non-competitive rate regulatory categories are presented. After the results under the various different rate regulatory laws are grouped under the two broad regulatory classifications, the observed differences are reversed and less dramatic than those for the extremes in each classification which were compared and contrasted above. 
Table 2.1

Comparison of mean loss ratios and mean market shares for competitive and non-competitive states for all automobile insurance lines during 1971-1980

\begin{tabular}{|c|c|c|c|c|}
\hline \multicolumn{5}{|c|}{ MEAN LOSS RATIOS } \\
\hline & Direct Writers & National Agency & Regional Companies & Industry \\
\hline Competitive States & $65.9 \%$ & $61.0 \%$ & $59.4 \%$ & $63.2 \%$ \\
\hline Non-Competitive States & 69.0 & 64.5 & 63.5 & 66.1 \\
\hline National & 67.6 & 63.2 & 61.7 & 64.9 \\
\hline Significance Level * & 0.2 & 55.9 & 1.3 & 8.4 \\
\hline
\end{tabular}

MEAN MARKET SHARES

\begin{tabular}{|c|c|c|c|}
\hline & Direct Writers & National Agency & Regional Companies \\
\hline Competitive States & $55.2 \%$ & $26.5 \%$ & $18.0 \%$ \\
\hline Non-Competitive States & 46.3 & 36.1 & 17.6 \\
\hline National & 50.1 & 32.0 & 17.8 \\
\hline Significance Level * & 0.1 & 0.0 & 98.5 \\
\hline
\end{tabular}

* Statistical significance of the difference between the values for competitive and noncompetitive rate states. The significance level shows the probability that the two values do not differ in a statistical sense.

Table 2.2

Comparison of mean loss ratios and mean market shares for competitive and non-competitive states for automobile liability insurance during 1971-1980

\begin{tabular}{|c|c|c|c|c|}
\hline \multicolumn{5}{|c|}{ MEAN LOSS RATIOS } \\
\hline & Direct Writers & National Agency & Regional Companies & Industry \\
\hline Competitive States & $65.1 \%$ & $62.0 \%$ & $60.2 \%$ & $63.3 \%$ \\
\hline Non-Competitive States & 69.1 & 65.8 & 64.8 & 66.6 \\
\hline National & 67.2 & 64.4 & 62.7 & 65.2 \\
\hline Significance Level * & 1,1 & 46.5 & 0.0 & 5.5 \\
\hline
\end{tabular}

MEAN MARKET SHARES

\begin{tabular}{lcccc} 
& Direct Writers & & National Agency & Regional Companies \\
\cline { 2 - 2 } Competitive States & $54.4 \%$ & & $28.4 \%$ & $17.0 \%$ \\
Non-Competitive States & 44.8 & & 38.6 & 16.6 \\
National & 49.0 & & 34.2 & 16.8 \\
Significance Level * & 0.0 & & 0.0 & 90.5
\end{tabular}

* Statistical significance of the difference between the values for competitive and noncompetitive rate states. The significance level shows the probability that the two values do not differ in a statistical sense. 
Table 2.3

Comparison of mean loss ratios and mean market shares for competitive and non-competitive states for automobile physical damage insurance during 1971-1980

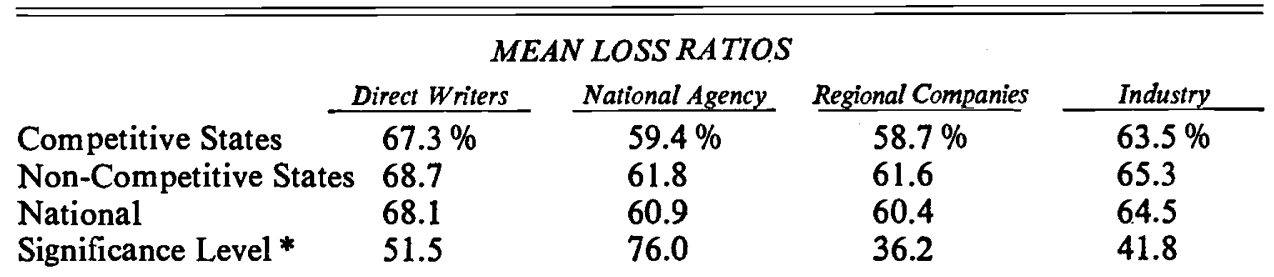

MEAN MARKET SHARES

\begin{tabular}{lcccc} 
& Direct Writers & & National Agency & Regional Companies \\
\cline { 2 - 2 } Competitive States & $56.3 \%$ & & $23.4 \%$ & \\
Non-Competitive States & 48.5 & & 32.2 & $19.7 \%$ \\
National & 51.6 & & 28.7 & 19.3 \\
Significance Level * & 0.3 & & 0.1 &
\end{tabular}

* Statistical significance of the difference between the values for competitive and noncompetitive rate states. The significance level shows the probability that the two values do not differ in a statistical sense.

\section{Mean Loss Ratios}

By examining the set of three tables, it can be observed that the mean loss ratios are slightly lower in the competitive rate states than in non-competitive rate states for each company group and for the entire industry for each automobile insurance line. However, the differences between these mean loss ratios for competitive and noncompetitive rate states are generally not significantly different in a statistical sense. There are some exceptions for the direct writers and regional companies for the combined automobile lines and for automobile liability insurance. The differences are not significant for these two company groups for automobile physical damage insurance. Thus, the results are somewhat mixed. Nevertheless, it can be observed that the mean loss ratios for these two groups of states are never significantly different than zero for the total industry in each line of insurance at the 5-percent level of significance. ${ }^{13}$

In general, the results in these tables show that the loss ratios are lower in competitive rate states than in non-competitive states, but they are not significantly different in a statistical sense for the entire industry. These results do not support our preliminary hypothesis because we expected that mean loss ratios would be higher in competitive rate states than in non-competitive ones. Based on the statistical results

13 It should be noted that a high probability figure corresponds to a low level of statistical significance and implies there is no significant difference between the mean loss ratios in such a case. In contrast, a low probability figure in one of the tables corresponds to a high level of statistical significance and implies that there may be a significant difference between the means loss ratios in the two groups of states. 
here, we are forced to reject this hypothesis and tentatively accept the alternative hypothesis that there is no significant difference in relative costs between competitive and non-competitive rate states.

If mean loss ratios are compared among company groups, a hierarchical relationship becomes evident for each line of automobile insurance. The direct writers have the highest loss ratios, the national agency companies have the second highest loss ratios, and the regional-speciality companies have the lowest loss ratios in both the competitive and non-competitive states and on a national basis. Thus, the direct writers appear to have returned a higher proportion of the premium dollar to consumers in the form of loss payments under either type of regulatory system, which may have some important economic efficiency implications. ${ }^{14}$

\section{Mean Market Shares}

By examining the mean market shares in the bottom of Tables 2.1, 2.2 and 2.3, it can be observed that the direct writers have been able to capture a higher market share in the competitive rate states than in the non-competitive ones. The low level of probability for each line indicates that this difference was highly significant in a statistical sense. The opposite relationship was found for national agency companies and was also significantly different than zero for each line of insurance. For the regional companies, the market shares are almost the same in the competitive and non-competitive rate states. Thus, they are not significantly different in a statistical sense as indicated by the high probability values.

Direct writers always had the largest market shares in competitive rate states, while national-agency companies had the largest shares in regulated, or non-competitive, rate states. These results may be indicative of the type of environment in which each company group performs best. The direct writers with relatively low prices are able to capture a larger share of the market in competitive rate states; whereas, the national agency companies were able to capture their largest share in non-competitive rate states.

If both mean loss ratios and mean market shares among the company groups are compared, a general hierarchical relationship is again evident. Direct writers always have the highest loss ratios and market shares in both the competitive and non-competitive rate states. The national agency companies have the second highest loss ratios and market shares, and the regional companies always had the lowest loss ratios and market shares.

\subsection{Summary}

In general, there was basically no significant difference between the mean loss ratios in competitive and non-competitive rate states for the entire auto insurance industry. In this respect, our hypothesis that mean loss ratios would be higher in competitive rate states than in non-competitive ones must be rejected, and the alternative of no difference must be tentatively accepted. However, it should be recalled that some

14 For an interesting analysis of the independent agency and direct writing system, see Joskow [4] and Cummins and Van Derhei [1]. 
non-trivial differences were found between mean loss ratios for some of the purest forms of rate regulatory laws in these two broad regulatory classifications. When less pure forms of rate regulatory laws are grouped in the competitive and non-competitive classifications, some major distinctions are blurred and the analysis reveals no significant differences between the mean loss ratios for these two groups of states. Nevertheless, these general results still would seem to suggest that the consumers' welfare has been served as well by competition as by administrative rate regulation. Thus, there appears to be little or no economic justification for rate regulation based upon relative cost comparisons.

\section{Analysis of underwriting risk and return}

\subsection{Nature of underwriting risk}

The total underwriting risk associated with a line of automobile insurance in a state for a company group or for the total industry, as indicated earlier, is composed of systematic and unsystematic components. The total variability in a state loss ratio over time is used as a proxy measure of the total underwriting risk faced by the various company groups in a state for a given line of insurance. This variability during 1971 through 1980 was calculated for each state and the District of Columbia for each company group and the total industry for each line of automobile insurance. A weighted average of the standard deviations associated with competitive and non-competitive rate states was also computed, along with the weighted national average. These weighted standard deviations are presented in Table 3.1, 3.2 and 3.3, along with the standard

Table 3.1

Comparison of standard deviations and coefficients of underwriting risk for competitive and non-competitive rate regulatory laws for all automobile insurance lines during 1971-1980

\begin{tabular}{|c|c|c|c|c|c|c|c|c|}
\hline \multicolumn{9}{|c|}{ STANDARD DEVIATIONS * } \\
\hline & \multicolumn{2}{|c|}{ Direct Writers } & \multicolumn{2}{|c|}{ National Agency } & \multicolumn{2}{|c|}{ Regional Companies } & \multicolumn{2}{|c|}{ Industry } \\
\hline \multirow[t]{4}{*}{$\begin{array}{l}\text { Competitive } \\
\text { Non-Competitive } \\
\text { National } \\
\text { Significance ** }\end{array}$} & \multicolumn{2}{|c|}{$\begin{array}{l}4.62 \\
5.82 \\
5.27 \\
6.0 \%\end{array}$} & \multicolumn{2}{|c|}{$\begin{array}{c}5.50 \\
5.40 \\
5.44 \\
85.40 \%\end{array}$} & \multicolumn{2}{|c|}{$\begin{array}{c}4.45 \\
5.01 \\
4.76 \\
24.50 \%\end{array}$} & \multicolumn{2}{|c|}{$\begin{array}{c}4.81 \\
5.55 \\
5.24 \\
21.80 \%\end{array}$} \\
\hline & \multicolumn{8}{|c|}{ STANDARD DEVIATIONS FOR SELECTED STATES } \\
\hline & \multicolumn{2}{|c|}{ Direct Writers } & \multicolumn{2}{|c|}{ National Agency } & \multicolumn{2}{|c|}{ Regional Companies } & \multicolumn{2}{|c|}{ Industry } \\
\hline & $S D$ & $\underline{\text { Rank }}$ & $S D$ & Rank & $S D$ & $\underline{\text { Rank }}$ & $S D$ & Rank \\
\hline $\begin{array}{l}\text { California } \\
\text { Illinois } \\
\text { Texas } \\
\text { National }\end{array}$ & $\begin{array}{l}3.55 \\
4.41 \\
7.59 \\
5.97\end{array}$ & $\begin{array}{r}45 \\
30 \\
8 \\
15\end{array}$ & $\begin{array}{l}4.52 \\
5.11 \\
7.29 \\
5.24\end{array}$ & $\begin{array}{r}30 \\
22 \\
6 \\
21\end{array}$ & $\begin{array}{l}4.01 \\
2.69 \\
7.51 \\
4.58\end{array}$ & $\begin{array}{r}39 \\
49 \\
9 \\
33\end{array}$ & $\begin{array}{l}3.88 \\
4.27 \\
7.97 \\
5.65\end{array}$ & $\begin{array}{r}38 \\
33 \\
5 \\
12\end{array}$ \\
\hline
\end{tabular}

* Standard deviations are measured in terms of percentage points.

** Statistical significance of the difference between the values for competitive and noncompetitive rate states. The significance level shows the probability that the two values do not differ in a statistical sense. 
Table 3.2

Comparison of standard deviations and coefficients of underwriting risk for competitive and non-competitive rate regulatory laws for automobile liability insurance during 1971-1980

\begin{tabular}{|c|c|c|c|c|c|c|c|c|}
\hline \multicolumn{9}{|c|}{ STANDARD DEVIATIONS * } \\
\hline & \multicolumn{2}{|c|}{ Direct Writers } & \multicolumn{2}{|c|}{ National Agency } & \multicolumn{2}{|c|}{ Regional Companies } & \multicolumn{2}{|c|}{ Industry } \\
\hline \multirow[t]{4}{*}{$\begin{array}{l}\text { Competitive } \\
\text { Non-Competitive } \\
\text { National } \\
\text { Significance ** }\end{array}$} & \multicolumn{2}{|c|}{$\begin{array}{l}5.19 \\
6.21 \\
5.72 \\
24.10 \%\end{array}$} & \multicolumn{2}{|c|}{$\begin{array}{c}6.06 \\
5.78 \\
5.83 \\
70.00 \%\end{array}$} & \multicolumn{2}{|c|}{$\begin{array}{l}5.65 \\
5.65 \\
5.65 \\
99.50 \%\end{array}$} & \multicolumn{2}{|c|}{$\begin{array}{l}5.34 \\
5.54 \\
5.45 \\
80.80 \%\end{array}$} \\
\hline & \multicolumn{6}{|c|}{ STANDARD DEVIATIONS FOR SELECTED STATES } & & \\
\hline & \multicolumn{2}{|c|}{ Direct Writers } & \multicolumn{2}{|c|}{ National Agency } & \multicolumn{2}{|c|}{ Regional Companies } & \multicolumn{2}{|c|}{ Industry } \\
\hline & $S D$ & $\underline{\text { Rank }}$ & $S D$ & $\underline{\text { Rank }}$ & $S D$ & $\overline{\text { Rank }}$ & $S D$ & Rank \\
\hline $\begin{array}{l}\text { California } \\
\text { Illinois } \\
\text { Texas } \\
\text { National }\end{array}$ & $\begin{array}{l}4.16 \\
3.79 \\
8.30 \\
4.59\end{array}$ & $\begin{array}{r}31 \\
36 \\
9 \\
29\end{array}$ & $\begin{array}{l}5.09 \\
4.52 \\
7.63 \\
4.07\end{array}$ & $\begin{array}{l}27 \\
35 \\
10 \\
41\end{array}$ & $\begin{array}{l}5.65 \\
3.11 \\
8.20 \\
4.48\end{array}$ & $\begin{array}{l}26 \\
46 \\
13 \\
34\end{array}$ & $\begin{array}{l}4.74 \\
3.41 \\
8.52 \\
4.31\end{array}$ & $\begin{array}{r}22 \\
35 \\
6 \\
24\end{array}$ \\
\hline
\end{tabular}

* Standard deviations are measured in terms of percentage points.

** Statistical significance of the difference between the values for competitive and noncompetitive rate states. The significance level shows the probability that the two values do not differ in a statistical sense.

Table 3.3

Comparison of standard deviations and coefficients of underwriting risk for competitive and non-competitive rate regulatory laws for automobile physical damage insurance during 1971-1980

\begin{tabular}{|c|c|c|c|c|}
\hline \multicolumn{5}{|c|}{ STANDARD DEVIATIONS * } \\
\hline & Direct Writers & National Agency & Regional Companies & Industry \\
\hline $\begin{array}{l}\text { Competitive } \\
\text { Non-Competitive } \\
\text { National } \\
\text { Significance ** }\end{array}$ & $\begin{array}{l}6.88 \\
8.10 \\
7.57 \\
3.40 \%\end{array}$ & $\begin{array}{c}6.56 \\
7.62 \\
7.24 \\
10.50 \%\end{array}$ & $\begin{array}{l}5.05 \\
6.97 \\
6.16 \\
0.30 \%\end{array}$ & $\begin{array}{l}6.33 \\
7.86 \\
7.25 \\
0.90 \%\end{array}$ \\
\hline
\end{tabular}

STANDARD DEVIATIONS FOR SELECTED STATES

\begin{tabular}{|c|c|c|c|c|c|c|c|c|}
\hline & \multicolumn{2}{|c|}{ Direct Writers } & \multicolumn{2}{|c|}{ National Agency: } & \multicolumn{2}{|c|}{ Regional Companies } & \multicolumn{2}{|c|}{ Industry } \\
\hline & $S D$ & Rank & $S D$ & Rank & $S D$ & Rank & $S D$ & Rank \\
\hline $\begin{array}{l}\text { California } \\
\text { Illinois } \\
\text { Texas } \\
\text { National }\end{array}$ & $\begin{array}{l}7.37 \\
7.53 \\
7.19 \\
8.27\end{array}$ & $\begin{array}{l}27 \\
23 \\
30 \\
14\end{array}$ & $\begin{array}{l}5.95 \\
7.22 \\
6.98 \\
7.29\end{array}$ & $\begin{array}{l}31 \\
19 \\
.21 \\
17.5\end{array}$ & $\begin{array}{l}3.78 \\
5.43 \\
6.91 \\
4.96\end{array}$ & $\begin{array}{l}48 \\
34 \\
22 \\
38\end{array}$ & $\begin{array}{l}6.44 \\
7.11 \\
7.46 \\
7.60\end{array}$ & $\begin{array}{l}34 \\
24.5 \\
17 \\
16\end{array}$ \\
\hline
\end{tabular}

* Standard deviations are measured in terms of percentage points.

** Statistical significance of the difference between the values for competitive and noncompetitive rate states. The significance level shows the probability that the two values do not differ in a statistical sense. 
deviations for a few selected states which illustrate the extremes in the competitive and non-competitive rate regulatory categories.

By examining the tables, it can be seen that there was greater underwriting risk in non-competitive rate states than in competitive ones for every company group and for each line of insurance. However, these differences were not generally significant in the statistical sense, except for physical damage insurance.

This absolute measure of underwriting risk, the standard deviation, suggests that there is little support for a hypothesis that companies face greater total underwriting risk in non-competitive rate states than in competitive ones, except for the direct writers. However, this probably is not the appropriate measure for determining differences in underwriting risk among states. A more relevant test should probably be based on the systematic component of the variability in loss ratio for a state or group of states. Such an analysis is developed in the following sections.

\subsection{Systematic and unsystematic underwriting risk and "return"}

The annual statewide loss ratios by company group for each line of insurance were regressed on the annual national loss ratio for the combined lines of automobile insurance on a modified basis for 1971 through 1980 in order to obtain some additional economic insights about the effect of rate regulation on insurers. This is a linear regression model which attempts to capture the relationship between the loss ratio in a state for a given line of insurance and the national loss ratio for the combined automobile insurance lines over the ten-year period. These regressions were developed separately for each state and the District of Columbia for each of the three types of company groups and for the total industry by line of automobile insurance. In total, 612 regressions were run. However, only some summary results will be presented in the following tables in order to economize on space.

\section{The Nature of the Regression Model}

A statistical regression model was utilized to partition the unsystematic and systematic components of underwriting risk. For reasons based on ease of statistical interpretation, the annual state loss ratios by line of insurance were not regressed directly on the national loss ratios for the combined lines. Rather, deviations of the annual state loss ratios from the average annual national loss ratio for the combined lines of insurance for the ten-year period 1971 through 1980 were regressed on the deviations of the annual national loss ratios for all lines from its average during this period. This modified approach allows a simplified interpretation of the regression constant, alpha, in the regression model specified below. This constant merely shows whether the average state loss ratio was above or below the average national loss ratio for the combined automobile insurance lines during the ten-year time period.

The regression model utilized to test the state loss ratio is specified below.

$$
L R_{i, j, k, t}-\overline{N L R}=\alpha_{i, j, k}+\beta_{i, j, k}\left(N L R_{t}-\overline{N L R}\right)+\varepsilon_{i, j, k}
$$

where 
$L R_{i, j, k, t}=$ the annual loss ratio for state $i$, company group $j$, and insurance line $k$ during year $t$;

$N L R_{t}$ = the annual national loss ratio for all automobile insurance lines during year $t$;

$\overline{N L R}=\sum_{t=1}^{10} N L R_{t} / 10=$ the average national loss ratio for all automobile insurance lines during the years 1971 through 1980 ;

$\alpha_{i, j, k}=\mathrm{a}$ regression constant, alpha, which denotes the difference between the average national loss ratio and the average loss ratio for state $i$, company group $j$, and insurance line $k$ (it is a measure of the unsystematic portion of the excess loss ratio in a state for a given automobile insurance line);

$\beta_{i, j, k}=a$ regression coefficient, beta, which measures the relative systematic underwriting risk in state $i$, for company group $j$ and insurance line $k$;

$\varepsilon_{b, j, k}=$ a stochastic error term which captures the unsystematic component of underwriting risk in state $i$, for company group $j$ and insurance line $k$ (it captures factors that do not influence the national loss ratio for the combined automobile insurance lines).

\section{A Theoretical Partitioning of Loss Ratios}

Based on the regression model, the loss ratio for a state for a given line of insurance can be analyzed in a risk and "return" framework. The "return" is defined to be an inverse or indirect measure of underwriting profit because an average loss ratio is used as the measure. Underwriting profit varies inversely with an average loss ratio, other things being equal. The "return" or inverse return portion of the loss ratio for a state can be divided into two parts : one dependent on the national loss ratio and the second independent of the national loss ratio. The first component will be referred to as the systematic "return" and the second as the unsystematic "return". Thus, the total loss ratio for a line of insurance is equal to the sum of the systematic and unsystematic " return" components.

The systematic "return" portion of the loss ratio is a direct function of the national loss ratio for automobile insurance, so it can be expressed as a factor designated as beta times the national loss ratio. In this "return" context, beta in the above regression model can be viewed as an economic sensitivity index which indicates how sensitive the loss ratio for a given automobile insurance line in a state is to changes in the national loss ratio. ${ }^{15}$

The unsystematic part of the loss ratio, which is independent of the national loss ratio, is the remaining portion of the state loss ratio. Alpha in the modified regression model above represents the unsystematic portion of the excess average state loss ratio over the average national loss ratio. The average value of the stochastic error term, epsilon, over time should be near zero and alpha should be equal to the average

15 The national beta for an automobile insurer would merely be a weighted average of the individual betas associated with each state in which they wrote the given line of insurance. The weights used in calculating such an average would have to be proportional to the premiums or exposures they wrote in each state, other things being equal. 
temporal value of the unsystematic " return" component of the excess state loss ratio. The value of alpha for a state would show whether the average state loss ratio for a given line of automobile insurance was greater than or less than the average national loss ratio during a given time period, depending on whether it was positive or negative. In this sense, alpha captures the state-specific portion of the excess state loss ratio. If alpha is greater than zero, this suggests the state-specific effects tend to raise the loss ratio ; whereas, if alpha is less than zero, it suggests the state-specific effects tended to decrease the state loss ratio, other things being equal.

\subsection{Systematic and unsystematic underwriting risk}

Based on the two-part theory of state loss ratios above, the specification of the systematic and unsystematic components of underwriting risk is straightforward - they are simply the standard deviations associated with the two "return " components of the loss ratio. The systematic underwriting risk associated with the loss ratio for a given line of insurance in a state is equal to the beta of the state times the standard deviation of the national loss ratio for all automobile insurance lines. The unsystematic risk in the regression model is equal to the residual standard deviation or the variability that is not explained by the variability in the national loss ratio for automobile insurance. This unique risk stems from the many economic, political, and social factors that are peculiar to a state. It is state-specific variation or unsystematic underwriting risk in that it is unrelated to common national factors or effects.

Since an automobile insurer theoretically can eliminate the unsystematic underwriting risk by diversifying its porfolio across states, one would not expect a fully competitive market to offer a risk premium for bearing such risk. In this regard, regional-speciality insurers would be at a competitive disadvantage unless they would maintain lower relative losses or expenses than their national competitors. ${ }^{16}$ In contrast, systematic underwriting risk (a form of business risk) cannot be eliminated by the diversification across states because it is related to national market forces. Therefore, beta is a relative measure of the systematic underwriting risk for automobile insurance in a state because it is related to the risk of the insurance market index, which is the national loss ratio for automobile insurance in this case. For convenience of exposition, systematic underwriting risk hereafter will be discussed in relative terms, that is, in terms of beta rather than in terms of the absolute measure of the systematic underwriting risk, which is beta times the standard deviation of the national loss ratio for all automobile insurance lines.

Since the beta for a state is a relative measure of the systematic underwriting risk, it captures the national economic effects or market forces that tend to make state loss ratios for automobile insurance vary over time on a systematic basis. There are numerous economic forces and business perils on a national basis that influence loss ratios, such as inflation, oil embargos, changes in monetary and fiscal policy, and various other factors. All of these forces and perils have an impact on state loss ratios, as well as on the national loss ratio and cannot be eliminated by diversification of

16 Neil Doherty, at the University of Illinois, brought this point to the attention of the senior author. 
automobile insurance among states. Beta captures these common factors among states that influence loss ratios on a joint basis.

\subsection{Systematic underwriting risk by state}

For each state and the District of Columbia, a statewide loss ratio for a line of automobile insurance was regressed on the national loss ratio for all automobile insurance lines. ${ }^{17}$ This was done separately for each company group (the direct writers, national agency companies, regional companies, and the total industry) and separately for each line of automobile insurance (liability, physical damage, and both lines combined). These results are only summarized here for four states and the competitive and non-competitive group of states.

The results for four states (California, Illinois, New Jersey, and Texas) are presented in Tables 4.1, 4.2, and 4.3. These states were chosen in order to dramatize the differences between the extremes in the competitive and non-competitive regulatory classifications. California and Illinois, as noted earlier, are states with highly competitive types of rate regulatory laws. In the non-competitive category, New Jersey has a prior-approval law, and Texas has rates set by the State Board of Insurance.

\section{Table 4.1}

Comparison of betas in selected states and in states with competitive and non-competitive rate regulatory laws for all automobile insurance lines during 1971-1980

\begin{tabular}{|c|c|c|c|c|c|c|c|c|}
\hline \multicolumn{9}{|c|}{ WHEIGHTED BETAS FOR COMPETITIVE AND NON-COMPETITIVE RATE STATES } \\
\hline Type of State Law & \multicolumn{2}{|c|}{ Direct Writers } & \multicolumn{2}{|c|}{ National Agency } & \multicolumn{2}{|c|}{ Regional Companies } & \multicolumn{2}{|c|}{ Industry } \\
\hline $\begin{array}{l}\text { Competitive } \\
\text { Non-Competitiv } \\
\text { Significance** }\end{array}$ & \multicolumn{2}{|c|}{$\begin{array}{l}0.85 \\
1.15 \\
2.5 \%\end{array}$} & \multicolumn{2}{|c|}{$\begin{array}{l}0.84 \\
1.05 \\
8.5 \%\end{array}$} & \multicolumn{2}{|c|}{$\begin{array}{c}0.92 \\
1.03 \\
35.2 \%\end{array}$} & \multicolumn{2}{|c|}{$\begin{array}{l}0.88 \\
1.09 \\
6.2 \%\end{array}$} \\
\hline \multicolumn{9}{|c|}{ BETAS FOR SELECTED STATES } \\
\hline \multirow[t]{2}{*}{$\underline{\text { State }}$} & \multicolumn{2}{|c|}{ Direct Writers } & \multicolumn{2}{|c|}{ National Agency } & \multicolumn{2}{|c|}{ Regional Companies } & \multicolumn{2}{|c|}{ Industry } \\
\hline & Beta & $\underline{R a n k}$ & Beta & $\underline{\text { Rank }}$ & Beta & $\underline{\text { Rank }}$ & Beta & $\underline{R a n k}$ \\
\hline $\begin{array}{l}\text { California } \\
\text { Illinois } \\
\text { New Jersey } \\
\text { Texas } \\
\text { National }\end{array}$ & $\begin{array}{l}0.77^{*} \\
0.88^{*} \\
1.94^{*} \\
1.46^{*} \\
1.01\end{array}$ & $\begin{array}{r}29 \\
24 \\
2 \\
7 \\
-\end{array}$ & $\begin{array}{l}0.74 \\
1.16 \\
1.81^{*} \\
1.25 \\
0.97\end{array}$ & $\begin{array}{r}30 \\
13 \\
2 \\
9 \\
-\end{array}$ & $\begin{array}{l}0.87 \\
0.69^{*} \\
2.31^{*} \\
1.02 \\
0.98\end{array}$ & $\begin{array}{r}26 \\
33 \\
1 \\
21 \\
-\end{array}$ & $\begin{array}{l}0.79 \\
0.94 \\
1.94^{*} \\
1.31^{*} \\
1.00\end{array}$ & $\begin{array}{r}30 \\
20 \\
2 \\
8 \\
-\end{array}$ \\
\hline
\end{tabular}

* Significantly different than one at a level of statistical significance of 10 percent or less.

** Statistical significance of the difference between the betas for competitive and noncompetitive rate states. The significance level as a percentage shows the probability that the two values do not differ in a statistical sense.

17 This regression model is based on the deviation forms as specified earlier, but for convenience and ease of exposition the simplified statement above will be used when no confusion will result. 
Table 4.2

Comparison of betas in selected states and in states with competitive and non-competitive rate regulatory laws for automobile liability insurance during 1971-1980

\begin{tabular}{|c|c|c|c|c|c|c|c|c|}
\hline \multicolumn{9}{|c|}{ WHEIGHTED BETAS FOR COMPETITIVE AND NON-COMPETITIVE RATE STATES } \\
\hline Type of State Law & \multicolumn{2}{|c|}{ Direct Writers } & \multicolumn{2}{|c|}{ National Agency } & \multicolumn{2}{|c|}{ Regional Companies } & \multicolumn{2}{|c|}{ Industry } \\
\hline $\begin{array}{l}\text { Competitive } \\
\text { Non-Competitiv } \\
\text { Significance** }\end{array}$ & \multicolumn{2}{|c|}{$\begin{array}{c}0.57 \\
0.84 \\
12.0 \%\end{array}$} & \multicolumn{2}{|c|}{$\begin{array}{c}0.59 \\
0.74 \\
31.3 \%\end{array}$} & \multicolumn{2}{|c|}{$\begin{array}{c}0.73 \\
0.74 \\
90.8 \%\end{array}$} & \multicolumn{2}{|c|}{$\begin{array}{c}0.61 \\
0.78 \\
24.3 \%\end{array}$} \\
\hline \multicolumn{9}{|c|}{ BETAS FOR SELECTED STATES } \\
\hline \multirow[t]{2}{*}{ State } & \multicolumn{2}{|c|}{ Direct Writers } & \multicolumn{2}{|c|}{ National Agency } & \multicolumn{2}{|c|}{ Regional Companies } & \multicolumn{2}{|c|}{ Industry } \\
\hline & Beta & Rank & Beta & Rank & Beta & Rank & Beta & Rank \\
\hline $\begin{array}{l}\text { California } \\
\text { Illinois } \\
\text { New Jersey } \\
\text { Texas } \\
\text { National }\end{array}$ & $\begin{array}{l}0.39^{*} \\
0.41^{*} \\
2.12^{*} \\
1.12^{*} \\
0.71^{*}\end{array}$ & $\begin{array}{r}30 \\
28 \\
1 \\
8 \\
-\end{array}$ & $\begin{array}{l}0.35 \\
0.77 \\
1.86^{*} \\
0.88 \\
0.69^{*}\end{array}$ & $\begin{array}{r}33 \\
17 \\
2 \\
14 \\
-\end{array}$ & $\begin{array}{l}0.65 \\
0.20^{*} \\
2.34^{*} \\
1.01 \\
0.74^{*}\end{array}$ & $\begin{array}{r}24 \\
42 \\
2 \\
12 \\
-\end{array}$ & $\begin{array}{l}0.41^{*} \\
0.49^{*} \\
2.05^{*} \\
1.01^{*} \\
0.71^{*}\end{array}$ & $\begin{array}{r}31 \\
28 \\
1 \\
10 \\
-\end{array}$ \\
\hline
\end{tabular}

* Significantly different than one at a level of statistical significance of 10 percent or better.

** Statistical significance of the difference between the betas for competitive and noncompetitive rate states. The significance level as a percentage shows the probability that the two values do not differ in a statistical sense.

\section{Table 4.3}

Comparison of betas in selected states and in states with competitive and non-competitive rate regulatory laws for automobile physical damage insurance during 1971-1980

\begin{tabular}{|c|c|c|c|c|}
\hline \multicolumn{5}{|c|}{ WHEIGHTED BETAS FOR COMPETITIVE AND NON-COMPETITIVE RATE STATES } \\
\hline Type of State Law & Direct Writers & National Agency & Regional Companies & Industry \\
\hline $\begin{array}{l}\text { Competitive } \\
\text { Non-Competitiv } \\
\text { Significance** }\end{array}$ & $\begin{array}{l}1.38 \\
1.63 \\
3.5 \%\end{array}$ & $\begin{array}{l}1.39 \\
1.67 \\
3.5 \%\end{array}$ & $\begin{array}{l}1.21 \\
1.47 \\
7.3 \%\end{array}$ & $\begin{array}{l}1.35 \\
1.62 \\
2.9 \%\end{array}$ \\
\hline
\end{tabular}

BETAS FOR SELECTED STATES

\begin{tabular}{|c|c|c|c|c|c|c|c|c|}
\hline \multirow[t]{2}{*}{ State } & \multicolumn{2}{|c|}{ Direct Writers } & \multicolumn{2}{|c|}{ National Agency } & \multicolumn{2}{|c|}{ Regional Companies } & \multicolumn{2}{|c|}{ Industry } \\
\hline & Beta & Rank & Beta & Rank & Beta & Rank & Beta & Rank \\
\hline California & 1.56 & 21 & $1.59^{*}$ & 16 & 1.14 & 33 & $1.52^{*}$ & 20 \\
\hline Illinois & $1.67^{*}$ & 19 & $1.99^{*}$ & 8 & $1.50^{*}$ & 21 & $1.73^{*}$ & 12 \\
\hline New Jersey & $1.67^{*}$ & 18 & $1.76^{*}$ & 12 & $2.28^{*}$ & 6 & $1.79^{*}$ & 9 \\
\hline Texas & $1.85^{*}$ & 12 & $1.85^{*}$ & 10 & 1.09 & 36 & $1.71^{*}$ & 14 \\
\hline National & $1.52^{*}$ & - & $1.57^{*}$ & - & $1.36^{*}$ & - & $1.52^{*}$ & - \\
\hline
\end{tabular}

* Significantly different than one at a level of statistical significance of 10 percent or better.

** Statistical significance of the difference between the betas for competitive and noncompetitive rate states. The significance level as a percentage shows the probability that the two values do not differ in a statistical sense. 
By examining these tables, it can be seen that the betas in the two competitive rate states were usually less than one and always lower than those in New Jersey and Texas, which were usually greater than one, for the combined automobile insurance lines and for automobile liability insurance. The betas for automobile physical damage insurance were always greater than one for these four states and all other states. This seems to indicate that automobile insurers have much less control over loss ratios for automobile physical damage insurance than they do for automobile liability insurance. Morevoer, it should be noted that there is no specific pattern for the betas among the two competitive and two non-competitive rate states for physical damage insurance. Thus, the only conclusion possible is that automobile insurance companies seem to face less systematic underwriting risk in highly competitive rate states than in the less competitive ones for automobile liability insurance and the combined automobile insurance lines. The nature of the competitive rate regulatory law appears to have little or no influence on the beta for automobile physical damage insurance.

For New Jersey and Texas, it should be noted that their betas were almost always greater than one for all automobile insurance lines. This seems to indicate that companies writing in these states face greater systematic underwriting risk than the national average, even in the automobile liability area. If companies writing in these states do not receive relative higher underwriting profits or incur lower underwriting losses, on a comparative basis it might be difficult for them to justify their exposure to the higher systematic underwriting risk they face in these states. This underwriting risk appears to be imposed by or closely associated with the rate regulatory system. New Jersey has exceptionally high betas for all company groups and the total industry for all automobile insurance lines. The betas for the regional companies in New Jersey indicate that the systematic variability in their loss ratios is close to 100 percent higher than the variability in the national loss ratio. This seems to suggest that rate regulation has had an extremely adverse effect on the stability of their loss ratios. The fact they are regional companies and do not diversify their automobile insurance business across many states implies that regulatory constraints have had an adverse impact on their underwriting results. Thus, the probability of insolvency for companies writing most of their automobile insurance business in New Jersey may have been increased dramatically by rate regulation. ${ }^{18}$

\subsection{Systematic underwriting risk in competitive and non-competitive rate states}

In the top portion of Tables 4.1 through 4.3 , weighted betas by company group for competitive and non-competitive rate states are presented for each line of automobile insurance. The weights used are based on the premium volume for each category shown in these tables. Hence, states with larger premiums have relatively higher weights assigned to their betas. 19

18 It might also be noted that the betas for every company group in New Jersey were significantly greater than one at a level of significance of about 5 percent or better. Clearly, New Jersey illustrates an extreme type of rate regulation.

19 These weights were also conditioned upon the premium volume of the company group under consideration and the line of insurance. 
By examining the weighted average betas for the combined lines of automobile insurance in Table 4.1, it can be seen that they were always lower in the competitive rate states than in the non-competitive ones for all company groups. Moreover, the weighted betas in the competitive rate states were always less than one; whereas, they were always greater than one in the non-competitive rate states. The differences between the weighted betas for competitive and non-competitive states for each company group and the industry were statistically significant at 8.5 percent or better, except for the regional companies.

For automobile liability insurance and physical damage insurance separately, the results are somewhat different from those on a combined basis. By examining Tables 4.2 and 4.3 , it can be seen that the weighted average betas in the competitive rate states were always less than the betas in the non-competitive rate states for all company groups in both lines of insurance. Thus, there is less systematic underwriting risk in the competitive rate states than in the non-competitive ones for both liability and physical damage insurance, but the differences are much more significant in the physical damage area. This corresponds with the result obtained on a combined basis.

An interesting result here is that the average betas for liability insurance are always less than one; whereas, the average betas for automobile physical damage insurance are always greater than one. This corresponds to what was found for the four states analyzed earlier.

Why the betas are always greater than one for physical damage insurance is not entirely clear. However, this may result from the fact that inflation may have a more direct and faster impact on physical damage insurance than on automobile liability insurance. Liability and physical damage premiums are both collected in advance. However, physical damage claims are normally paid shortly after they occur ; whereas, liability losses usually take longer to settle. This lag between the occurrence of the loss and when the payment is made may allow the insurer to estimate the impact of the inflation on losses of liability insurance more accurately and thus allow more precise pricing. This is not the case for physical damage insurance. In this regard, automobile insurers may have more control over the loss ratio in the automobile liability insurance than in the physical damage insurance. ${ }^{20}$

Our hypothesis about the impact of rate regulation on betas should be recalled. The betas were expected to be greater in non-competitive rate states than in states with competitive rate regulatory laws because we thought that stringent rate regulation would tend to make the systematic component in loss ratios more variable over time due to the delays inherent in the regulatory review process, which tend to make rate adjustments uneven and rates somewhat sticky. In contrast, since the rates can be adjusted to reflect changing loss conditions more rapidly in competitive rate states, one would expect the systematic component of loss ratios in these states to be less variable over time. Some statistical support for this hypothesis was found above for he combined automobile insurance lines.

20 The loss ratio data analyzed were based on calendar-year accounting results reported in annual statements of insurers rather than policy-year data, which would have been preferred. 
When beta is greater than one, this indicates that the loss ratio in a state increases or decreases more than the corresponding changes in the national loss ratio and that there is greater systematic variability in the loss ratios in such states. ${ }^{21}$ Accordingly, the systematic underwriting risk in non-competitive rate states appears to be greater than the underwriting risk associated with the national loss ratio for the combined automobile insurance lines. Therefore, these results suggest that state loss ratios tend to fluctuate more strongly than the national loss ratio in non-competitive rate states, especially for direct writers.

Since the weighted average betas in non-competitive rate states were greater than one for the combined automobile insurance lines, this would seem to indicate that rate regulation tends to create greater systematic underwriting risk for automobile insurers. This empirical result has a number of important economic implications.

First, a beta greater than one suggests that the net effect of rate regulation is to destabilize state loss ratios and to increase the probability of insolvency for companies operating in states with non-competitive rate regulatory laws. This is a perverse result because the basic purpose of regulation is to prevent insolvency of insurance companies. To the extent that state rate regulation increases the probability of insolvency by increasing the systematic variability in loss ratios, one of the basic principles of insurance regulatory theory is violated. Hence, a strong argument could be made for eliminating rate regulation in order to decrease the probability of insolvency and to promote the solvency of insurers. It would also free up resources dissipated on the rate regulatory process.

Second these results would seem to suggest that insurers could decrease the amount of systematic underwriting risk they face on a national basis by increasing their market shares in competitive rate states because these states had betas less than one. Increasing marketing efforts in states with betas less than unity could decrease the aggregate beta a company faces in automobile insurance. However, this would only apply to companies who write automobile insurance in many states or on a national basis. The direct writers appear to follow such a strategy because, as shown earlier, they have larger market shares in competitive rate states than in non-competitive ones. Regional-speciality companies obviously could not follow such a strategy unless they had a large enough marketing area that covered several competitive and non-competitive rate states.

In general, these results seem to suggest that restrictive rate regulation increases the systematic underwriting risk faced by automobile insurers because they are unable to adjust their rates to reflect changing loss conditions as rapidly as they can in competitive rate states. In addition, for a company writing automobile insurance in only one state, beta reflects an uncontrollable or "undiversifiable" form of underwriting risk that cannot be reduced. However, for a company writing in more than one state this systematic risk is not completely uncontrollable, as indicated above, because a

21 If the loss ratio in a state were perfectly and positively correlated with the national loss ratio, the beta for the state would be equal to one. If beta were greater than one, this would imply the loss ratio in a state fluctuated more than the national loss ratio and there was greater systematic underwriting risk in such a state. If beta were less than one, it would indicate that the state loss ratio fluctuated less than the national automobile insurance loss ratio and there was less systematic underwriting risk associated with such a state. 
company can reduce its aggregate beta by increasing its market share in states with low betas. ${ }^{22}$ Of course, there are some constraints on insurance diversification for companies who write in all states. They cannot dramatically decrease their market shares in automobile insurance in non-competitive rate states with high betas because of certain institutional constraints imposed on them by their agency force and by economic considerations associated with other lines of insurance they market in a state.

\section{Summary and concluslons}

A comparative economic analysis of relative costs and underwriting risk in automobile insurance markets by state, company group, and line of automobile insurance in the U.S.A. was developed based on some empirical loss ratio data for 1971 through 1980. It was found that there were basically no significant differences between the mean loss ratios or relative prices in competitive and non-competitive rate states. However, some differences were found between the purest forms of laws in these two rate regulatory categories, which seem to support our hypothesis that the mean loss ratios would be higher or relative prices would be lower in competitive rate states. In other words, the highest relative prices were found in non-competitive or highly regulated rate states. Nevertheless, the empirical results for all states seem to suggest that rate regulation has little effect on equilibrium levels of relative prices in the long run. Thus, no useful economic purpose appears to be served by rate regulation because regulators have no control over economic factors, such as inflation, which drive prices up. Artifcial political constraints on rates merely create availability and reliability problems in automobile insurance markets.

In regard to the rate regulatory standards for inadequacy and excessiveness, the results of this study seem to suggest that competitive market forces can protect both consumers and insurers as well as these vague standards. Regular financial audits and relatively high minimum capital and surplus requirements would be a better way to assure the solvency of insurers. When automobile insurance markets are competitively structured, as they are in most states, competitive market forces can probably determine equilibrium levels of insurance prices in a more efficient manner than politically pressured and influenced regulators.

Market share data by state, company group, and automobile insurance line were also analyzed. We found the direct writers had larger mean market shares in competitive rate states than in non-competitive ones. The opposite relationship was found for national agency companies. These results seem to suggest that the competitive pricing practices of direct writers were more successful in states with little or no rate regulation than in highly regulated ones. Although rate regulation appeared to constrain direct writers in non-competitive rate states, they still captured the largest share of the market in these states. The direct writers also had the highest loss ratios or lowest

22 It should be noted that some negative betas were found in a few states for some of the company groups and lines of insurance. 
relative prices in both the competitive and the non-competitive rate states. Nevertheless, rate regulation appears to impair the ability of direct writers to compete effectively against national agency companies in highly regulated rate states. Thus, rate regulation probably denies consumers some of the benefits provided by a competitive market place because it may mislead them into believing that prices do not differ among automobile insurers in highly regulated markets. As a result, they probably do not "price shop" as much.

The total underwriting risk faced by automobile insurers in competitive and noncompetitive rate states was also examined. In general, it was found that there was greater underwriting risk in non-competitive rate states than in competitive ones, which supported our basic hypothesis. However, these differences were usually not statistically significant. Total underwriting risk was measured by the temporal variation in loss ratios for a given line of insurance in a state. However, the standard deviation which was used to measure this variability may not be the appropriate measure for determining differences in underwriting risk between competitive and non-competitive states because it contains the systematic and unsystematic components of underwriting risk. In this respect, a relative measure of systematic underwriting risk, referred to as beta, was developed and used to measure how sensitive the loss ratio for a given line of automobile insurance in a state was to changes in the national loss ratio for all automobile insurance lines combined.

We expected to find greater systematic underwriting risk in non-competitive rate states than in competitive ones. We found some statistical support for this hypothesis. Our empirical results indicate that automobile insurers were subjected to greater systematic underwriting risk in highly regulated rate states than in competitive ones. Moreover, for the combined automobile insurance lines, the betas in the competitive rate states were always less than one ; whereas, they were always greater than one in the non-competitive rate states.

In general, the weighted average betas for competitive rate states were always less than the corresponding betas for the non-competitive rate states for each line of automobile insurance and for each company group. This would seem to indicate that rate regulation tends to destabilize state loss ratios and to increase the probability of insolvency faced by automobile insurance companies operating in these states. This is a very perverse result because the basic purpose of regulation is to prevent insolvencies of insurance companies. Thus, based on this result and the empirical observation that there is no significant difference in relative prices between competitive and non-competitive rate states, there seems to be little if any economic justification for rate regulation in competitively structured automobile markets.

If adminisrative rate regulation were eliminated, competitive market forces could determine equilibrium levels of insurance prices. Regulatory resources currently dissipated on political rituals associated with rate regulation could be reallocated to provide consumers with more information about automobile insurance contracts and their prices through the publication of buyer's guides. Information on claim settlement policies of insurance companies could also be provided in order to give consumers a better idea about the quality of the services sold by different insurance companies. Current availability problems in highly regulated rate states, as reflected by large numbers of insureds in assigned-risk plans, would probably also be reduced significantly if rates 
were not regulated. Although our study was restricted to state markets in the U.S.A., our results would seem to be relevant for public policy purposes in all countries with competitive market structures that regulate insurance rates.

\section{REFERENCES}

1. CUMMINS, D., and VANDERHEI, J.: “A note on the relative efficiency of propertyliability insurance systems", Bell Journal of Economics, 10 (Autumn 1979), 709-719.

2. GENERAL ACCOUNTING OFFICE OF THE UNITED STATES : Issues and Needed Improvements in State Regulation of the Insurance Industry, Report to the Congress of the United States by the General Accounting Office, October 1979.

3. IPPOLITO, R. A. : "The effects of price regulation in the automobile insurance industry", Journal of Law and Economics, 22 (April 1979), 55-89.

4. JOSKOW, P.L.: "Cartels, competition, and regulation in the property and liability insurance industry ", Bell Journal of Economics and Management Science, 4 (Autumn 1973), 375-427.

5. KIMBALL, S. L.: “The goals of insurance law : means versus ends", Journal of Risk and Insurance, 29 (March 1962), 19-29.

6. NATIONAL ASSOCIATION OF INSURANCE COMMISSIONERS : NAIC Report on Profitability by Line and by State for the Year 1978, Milwaukee (Wisc.), 1979.

7. NEW YORK INSURANCE DEPARTMENT : The Public Interest Now in Property and Liability Insurance Regulation, a Report of the New York Insurance Department to Governor Nelson S. Rockefeller, January 1969.

8. O'CONNOR, P.R., and CARLSON, K.: “Open competition versus prior approval: property and liability loss ratios, concentration ratios and operating profits", a paper prepared for the Society of Insurance Research, November 1979.

9. SAMPRONE, J.C., JR. : “Rate regulation and non-price competition in the property and liability insurance industry ", Journal of Risk and Insurance, 46 (December 1979), 683-696.

10. U.S. DEPARTMENT OF JUSTICE : The Pricing and Marketing of Insurance, a Report of the U.S. Department of Justice to the Task Group on Anti-Trust Immunity, Washington (D.C.), January 1977.

11. WITT, R.C.: "Pricing problems in automobile insurance: an economic analysis", Journal of Risk and Insurance, 40 (March 1973), 75-93.

12. WITT, R. C. : “The competitive rate regulatory system in Illinois : a comparative study by state ", CPCU Journal, 31 (September 1978), 151-162.

13. WITT, R.C.: "An economic appraisal of territorial pricing issues in automoblie insurance", Journal of Risk and Insurance, 46 (March 1979), 33-60.

14. WITT, R. C., and MILLER, H.: "A comparative analysis of relative cost under competitive and non-competitive rate regulatory laws", CPCU Journal, 33 (December 1980), 174-189.

15. WITT, R.C., and MILLER, H.: “Rate regulation, competition, and underwriting risk in automobile insurance markets", CPCU Journal, 34 (December 1981), 202-220. 